\title{
SQUARE AND STREET: SPATIAL AND FUNCTIONAL RELATIONS: THE PARTISANS` SQUARE IN UŽICE (1961)
}

Стручни рад, рад примљен: децембар 2017., рад прихваћен: јануар 2018.

Душко Кузовић*

\section{АПСТРАКТ}

Трг партизана је значајно остварење градитељске прошлости Југославије које садржи квалитетна урбанистичка и архитектонска решења. Рад анализира односе између два вида јавног простора (трга и улице) кроз неколико нивоа: ширина улице на месту улива у трг, профил уличног фронта, обрада волумена објекта на месту сустицања улице и трга, угао под којим се улица улива у трг, елементи који наглашавају место сустицања улице и трга, компоновање визура дуж главних пешачких токова, продори у нивоу партера објеката који затварају улични фронт ради повезивања простора трга са околином, начин обликовања улаза у објекте и улазних мотива, нивелација партера и улице на месту контакта, избор начина обликовања фасада према улици и тргу, избор материјала на месту додира партера трга и улице, садржај визуре кадра на правцима главних пешачких токова итд.

Кључне речи: Трг партизана у Ужицу, архитектура модерне у Србији, Станко Мандић, обликовање трга, трг и улица

\section{ABSTRACT}

Partisans' Square in Užice is a significant architectural achievement of Yugoslavia and contains numerous high-quality urban and architectural solutions. Paper analyzes relations between twolevels of the publicspace:thesquareand thestreets: Partisans' Square is a significant architectural achievement of the second Yugoslavia. Paper analyzes relations between two levels of the public space: the square and the streets. Relations between the two levels of public space are analyzed in order to better understand and evaluate the architecture of the originated period, and to describe urban solutions contributed to the high quality of the design. The square and the street are very carefully brought into the mutual relations: the width of the street at the point of entry into the market, the height of the streets front, the emphasis on the contact location of the street and square, the volume of the buildings, the street entering

\footnotetext{
* Assist.prof.dr Dusko Kuzovic dipl.ing.arch.,

angle in the market, the characteristic elements that emphasize the contact point, the composition of the vistas along the main pedestrian flows, breaks through the buildings at the level of parterre (to connect the sqare with the surrounding public spaces), the way of shaping the entrances into the buildings and the entrance motifs, the leveling of the square and the street at the contact point, the method of the facade designing in relation to the street and square, parterre touching point of the square and streets, the content of the point of view - the frame that appears in the eye of the beholder (from the direction of the main pedestrian flows), etc. All of these elements are based on the experience that can be found in the books about the urban design in Europe, in the public spaces of the Balkans, the great practical experience of the architect and his talent. The Partisans' Square was opened to the public in 1961 and, since then, is the most important public space in Užice. Although social values and norms have been changed over and over again, the market continues to provide the framework of public life in the best possible way and doesn't stop being the center of city life. The demolition of the Post Office building (1999), cracky lack of maintanance from 2000 until today, calls into question his survival. Architectural competitions, called to repair or improve the situation, confirmed only the quality and value of the solutions applied in the urban and architectural design. On the basis of aforementioned values the Partisans' Square in Užice deserves to be declared as a part of european cultural heritage.

Keywords: Partisans' Square in Užice, Modern Architecture in Serbia, Stanko Mandić, square design, square and street.

\section{1. УВОД}

Трг партизана у Ужицу се убраја међу најбоља остварења градитељства на простору Југославије у 20. веку. 0 њему су писали многобројни домаћи аутори (Миленковић, 1962; Максимовић, 1965; Митровић, 1965), страни стручни часописи (Аноним, 1964), савремени аутори (Ђокић, 2004, 2009; Бркић, 1992; Марковић, 2008; Миливојевић, 2013; Миливојевић, 2014; Цигановић, 2013), снимљени филмови (Први грађанин мале вароши, 1961) итд. Трг партизана, 


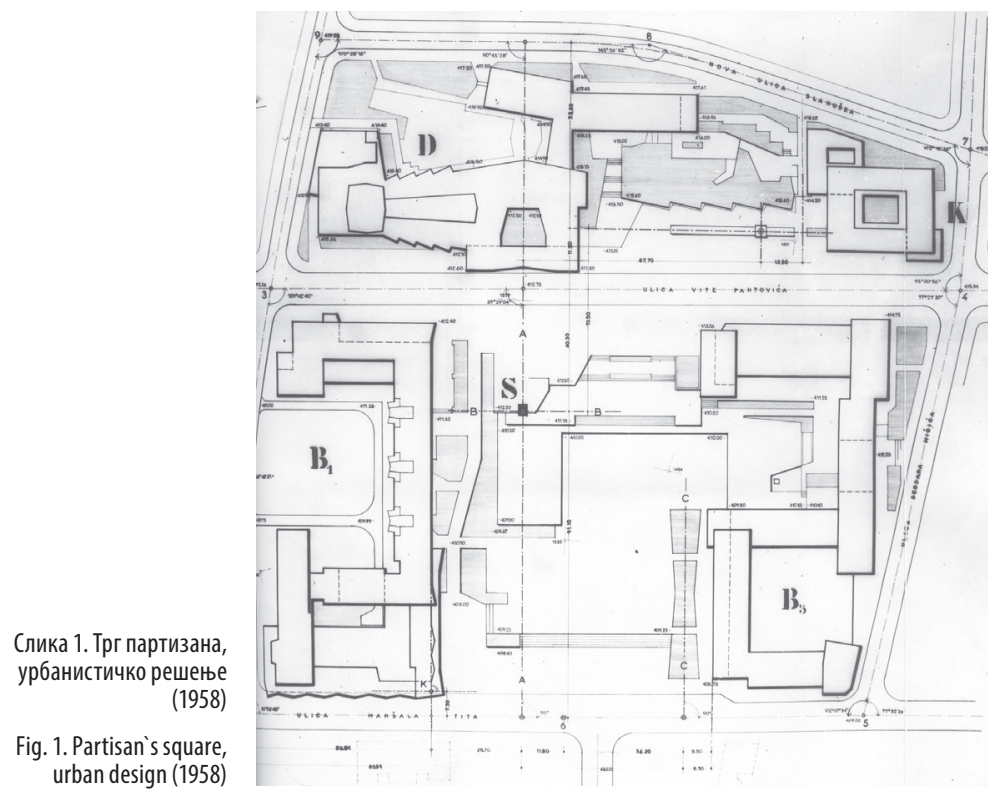

управо због квалитета урбанистичких решења, обележио је период друге Југославије. Међутим, упркос многобројним вредностима, Трг партизана није постао предмет стручне анализе. Шта више, урбанистичка и архитектонска решења заслужују да буду анализирана ради примене у савременој градитељској пракси. Овај рад, на примеру Трга партизана у Ужицу, анализира релацију између трга и улице. Циљ рада је да кроз анализу урбаниситичких и архитектонских решења специфицира пројектантске алате који могу да буду употребљиви и у савременој архитектонској пракси. За потребе рада користиће се писани материјали аутора (Мандић, 1959), техничка документација (Историјски архив Ужице, Архив града Ужица, приватни архиви) и писани радови (Бркић, 1992; Марковић, 1990).

\section{2. ТРГ, УЛИЦА И ЈАВНИ ПРОСТОР ГРАДА}

Централна зона Ужица је добила своје обличје у другој половини 19. века, када је формиран потез који се континуално пружа од Немањине улице до локације Алексића мост. На овом потезу, на главном друму који пролази кроз град, налази се неколико тргова (Ракијски, Светог Саве - Школски, Градски, Житни, Дрварски, Алексића). Неуједначеност у обликовању јавног простора (тргова и улица) од истока ка западу града настала је услед постепеног преузимања управљања градским простором од стране српског становништва: док су на истоку јавни простори дуго били у употреби (Школски, Градски, Ракијски трг) на западу су тек били у зачетку (Дрварски, Алексића трг). Простор за тргове у Ужицу је обезбеђен укидањем целокупних блокова или делова блокова. Уколико су јавни простори настајали на простору између две улице, форма је неправилна, а ако су настали укидањем површине блокова (након регулације насеља), форма је правилна. Распоред функција унутар простора трга опредељују сами грађани начином коришћења током времена, а не пројектант. (Сл. 2)
Простор који захвата Трг партизана ограничен је са четири улице на четири блока. Новине у урбанистичком обликовању које су унете са тргом односе се на концепцију градског блока, начин обликовања објекта у оквиру блока, компоновање фасаде, функцију у граду и обликовање јавног простора, начин сарадње архитектуре и трга, примену скулптуре и примену зеленила у јавном простору. Урбанистичким решењем трга је задржана стара саобраћајна мрежа у граду, јер није било могућности да се промене трасе саобраћајница. Поред тога, у урбанистичком обликовању након 1945. год. важила је препорука да се у обликовању блокова што мање задире у имовинске односе, а промена трасе улица би била уплив у ту област (Кузовић, 2015а). Корекције блока су извршене у домену концепције (слободностојећи објекти) и обликовања (вишеспратни објекти, трем у зони приземља, продори јавног простора кроз приземље објекта, обликовање волумена објеката, композиција фасада, итд.). (Сл. 3)

Од 1961. год., када је препуштен граду на коришћење, па до данас, трг има централну улогу у градском животу. Сви путеви становника града воде преко трга: ђаци прелазе преко њега пре и после школе, запослени пре и након посла, али и током паузе за доручак или кафу. Поред тога, трг је и простор за поподневни одмор, за игру деце, вечерњи излазак, дружење, политичке скупове, простор за прославу мале и велике матуре, представља старт и циљ ауто-мото трка, централно је место за протестне скупове, али и скупове подршке, на њему почиње и завршава се војна парада, једном речју, градски живот почиње и завршава се на тргу. Временом су уведени и нови садржаји на тргу, угоститељски простор је проширен на рачун јавног, али и након 50 година трг и даље има једнако важну улогу. Димензије простора, на почетку оцењене као превелике, временом су се показале као исправне. Једино је лоше процењен и испланиран простор за паркирање, које је тренутно решено на рачун пешачких простора. За урбанистичко и архитектонско пројектовање у Србији и Југославији овај трг је имао велики значај: био је деценијама место посете стручних путовања, а као део Музеја устанка против фашизма у Србији 1941. год. посетило га је за десет година преко 2,5 милиона туриста.

Током бомбардовања Србије 1999. год. срушена је Пошта (мада објекат није био војни циљ). Додатна девастација трга је учињена након бомбардовања, услед третирања трга као политичког репрезента времена у коме је саграђен. Неодржавањем је тада комплексу нанета додатна штета. 0бновом која није у складу са пројектованим стањем (слично, али не и исто), промењено је поплочавање, уклоњена је инкрустрација црним каменом у партеру, додати су призматични стубићи између Улице краља Петра и партера трга. Овим изменама, свесним или не, наглашена је улица, мада је архитекта Мандић учинио све како би прикрио улицу и спојио је у једну визуелну раван са партером трга. 
Расписани су урбанистички конкурси (2000) којима је требало да се реше „проблеми у обликовању трга” и архитектонски конкурси: први - којим је требало да се пројектују надградње свих објеката који се налазе на тргу (2007), и други - за нови објекат на месту срушене Поште. Наду да ће се девастација трга зауставити пружиле су изложба у Бечу одржана 2015. год. и иницијатива из исте године, поднета РЗ3СК у Београду, да се Трг партизана прогласи за културно добро (Кузовић, 2015е:102-118; 2015).

Како је говорио архитекта Мандић, да би архитекта могао да делује мора да нађе „чињенице струке” које су довољно конкретне да буду употребљиве приликом пројектовања: а) одредити површину простора, б) простор трга дефинисати „средствима архитектуре", г) водити рачуна 0 пропорцијским односима у композицији, д) у организацији трга остварити јединство у наменама, ђ) определити површине на тргу за посебне функције итд., односно, у најкраћем:
„....Tрг је синтеза простора дефинисаног архитектуром која га формира и наменом саме површине трга." (Мандић, 1959:26)

Утицаји локалне средине на пројектантско решење Трга партизана и улица, које је архитекта Мандић доживео као значајне и вредне разматрања, били су: котлина у којој се налази место, река, падине околних брда, клима и њен утицај на архитектонску форму и композицију, флора (Панчићева оморика) и грађевински материјал који је на располагању на локалном тржишту (локални камен, опека, локални клесари) (Мандић,1959:14).

Изазов и отежавајућа околност при изградњи Трга партизана је била чињеница да је пројектован и саграђен, за урбанизам, у веома кратком периоду (мање од три године), а не током деценија или векова када би се имало времена за дефинисање потреба грађана и карактера простора. Поред наведеног, неке од препорука које би требало да определе деловање архитекте у сличним задацима, према архитекти
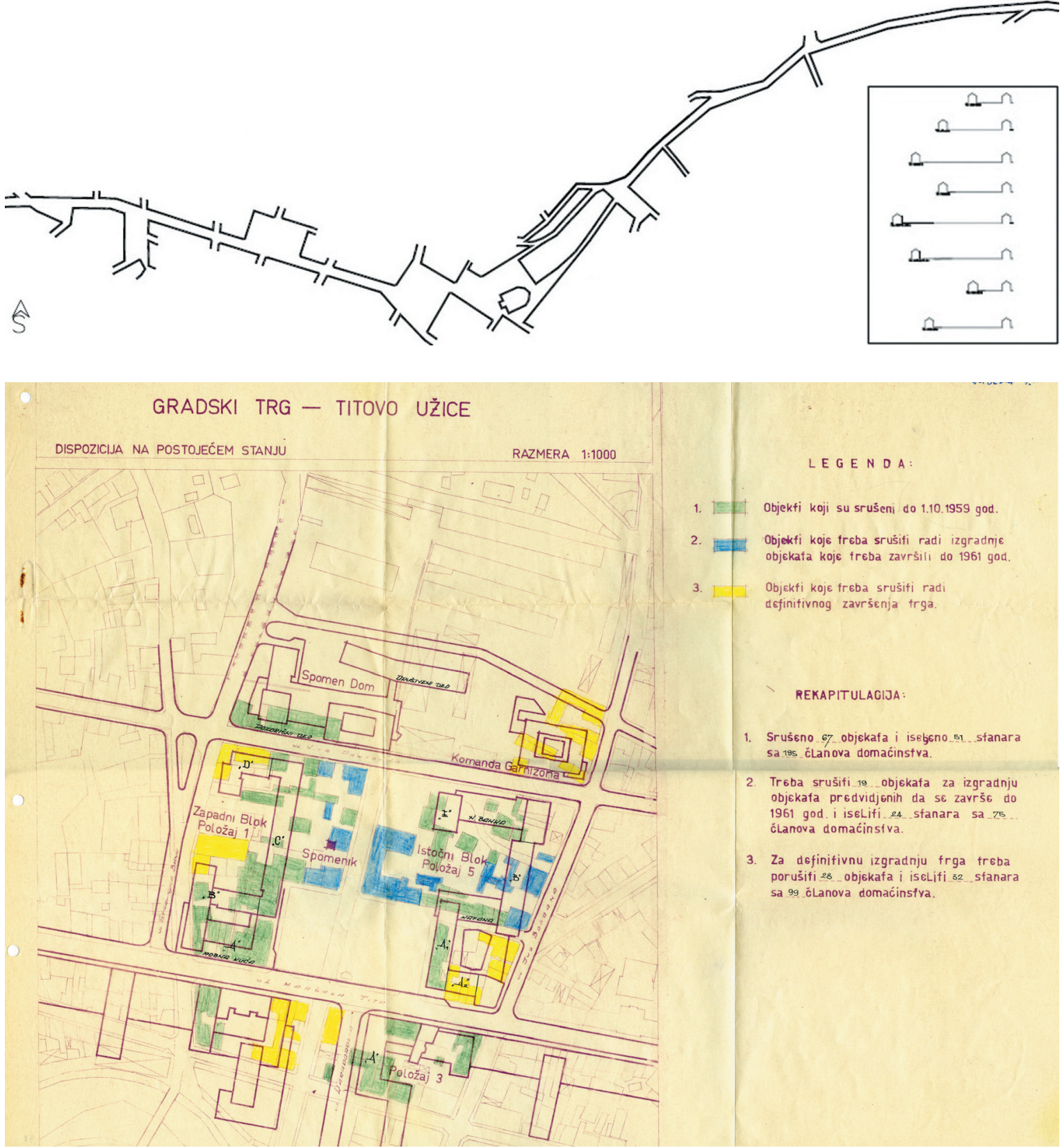

Слика 2. Јавни простори у Ужицу, стање 1891. године

Fig. 2. Continuity of the public space in Užice: the constant change of streets and squares formed along the main road

Слика 3. Трг партизана, однос старе и нове градске структуре

Fig. 3. Partisan's square, the relation between the old and the new city structure 


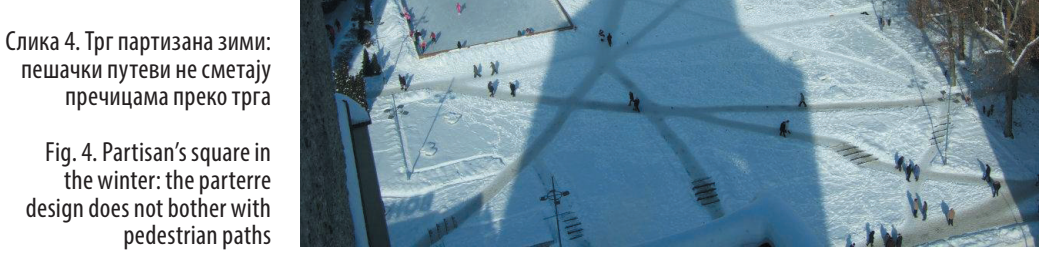

Мандићу, би биле: а) пројектантски приступ мора да буде изнад рутине, 6) истражити и уградити елементе локалне културе у пројекат, в) кренути у потрагу за аутохтоношћу пројекта, г) трг треба да носи обележје локалне културе, а не пројектанта, д) сваки објекат у себи садржи и регионалне и локалне елементе (Мандић, 1959:17). (Сл. 4)

\section{3. АРХИТЕКТУРА, ТРГ И УЛИЦА}

Архитектура објеката који граде улицу и особине јавне површине стварају осећај простора и атмосфере улице. На овај однос највећи утицај имају начин породичног живота и начела која воде урбанистичко уређење (Corbusier, L., Pierre, F., 1956; Corbusier, 1977). Историју Ужица карактеришу три периода: период отоманске управе (до 1863. год.), период изградње српске државе (од 1863. до 1961. год.) и период након 1961. год. (након изградње Трга партизана).

Током турске управе објекти на парцелама су били у средишту парцеле или повучени у односу на регулациону линију (регулациона линија у савременом смислу није постојала), око дворишта је грађен висок оградни зид (кућа и двориште не сарађују на формирању атмосфере улице), регулација улице је неправилна (улица је више саобраћајни коридор него улица), јединица суседства је махала (а не улица) (Кузовић, 20156; Кузовић, 2016а).

У периоду од 1863. до 1961. год., односно првих сто година српске управе, улице и регулациона линија су геометријски правилне (примена начела средњоевропског урбанизма), високе зидане ограде око окућнице су укинуте (двориште је део блока), објекти се налазе на регулационој линији (објекти формирају улицу), фасаде формирају правилан улични фронт (репрезентативна фасада је део куће, али и улице), спратност објеката је Пр или Пр+1 (профил улице се дефинише као однос ширине улице и висине уличне фасаде) итд. (Кузовић, 20136; Кузовић, 2013в; Илић, 1953).

у периоду након 1961. год., односно након изградње Трга партизана, улице се проширују (омогућују већу висину објеката), зграде су повучене у односу на регулациону линију (око зграда се формира зелени појас), објекти су слободностојећи (губи се осећај класичне улице), јединица суседства је Месна заједница (није махала или улица), спратност објеката је Пр+4 до Пр+11 (већа спратност мења карактер улице, блока и града), нови конструктивни систем, армирано-бетонска скелетна конструкција, омогућава повећање величине фасадних отвора, повећава се површина излога + прозора на рачун површине зиданог дела фасаде, кровови нису коси већ су равни, уводе се кровне терасе (Кузовић, 2015г).

Приватни живот је имао великог утицаја на регулацију Ужица-током отоманске управе приватни простор није смео да има комуникацију са јавним простором града. Након 1863. год., када је хришћанско становништво преузело власт у граду, приватни простор почиње да комуницира са јавним. Након 1945. год. јавни простори који се граде надмашују тренутне потребе заједнице (Група аутора, 1992; Кузовић, 2016а; Кузовић, 2015а; Кузовић, 20166). (Слика 05)

Сарадња објеката који формирају улични фронт и улице постигнута је моделовањем волумена објеката, ослобађањем фасаде у односу на грађевинску линију приземља, наглашавањем хоризонтала обликовањем фасаде (Арнхајм, 1990). Применом начела урбанизма 19. века у Ужицу и изграњом низа малих објеката (мали волумени, мала ширина уличног фронта), применом масивног конструктивног система (већа површина зида у односу на отворе) стваран је специфичан карактер улице. Након изградње Трга партизана, усвајају се нова начела урбанистичког, али и архитектонског пројектовања -фасаде су наглашене хоризонталама објеката које усмеравају поглед посматача да истражује даље низ улицу, и притом стварају утисак веће дужине улице него што то чине наглашене вертикале, али и мање висине објекта, коришћењем перспективе као алата композиције (Кузовић 2015д; Кузовић 2015ђ). Материјализација фасада објеката који формирају улицу (коришћењем пуног/празног и лаког/ тешког у композицији, вођењем рачуна о комбиновању текстура и боја примењених материјала, усклађивањем материјала на фасади и материјала у партеру испред објекта) допринела је изгледу трга.

Делови фасада на објектима су посебно обликовани како би били визуелно повезани са елементима у партеру: Народно позориште фасадом према тргу служи као пано-драперија за бронзану фигуру, а преко трема који покрива тротоар Улице краља Петра преплиће се са јавним површинама (Кузовић, 2015д); Пошта тремом који се пружа дуж јужне фасаде објекта, и који покрива тротоар, ствара јавни простор који дозвољава пешацима да се склоне, застану, одморе, друже и слично; Народна библиотека је повезана са композицијом трга преко дуге осовине која се преко њега пружа на падине брда (Кузовић, 20166); Робна кућа, захваљујући косој рампи, која се са нивоа партера трга пружа на први спрат објекта, повезује јавни простор са кровом објекта; Кула висином формира просторну доминанту -оријентир на тргу (Кузовић, 20166); Објекат Градске кафане се волуменом спрата надвија над тремом у приземљу који је јавна површина. (Сл. 6,8) 
Улазни мотиви у објекте су пажљиво обликовани и наглашени. У односу на главну фасадну раван, они су повучени и покривени (препуштањем виших етажа), улазни мотив је додатно наглашен обрадом партера, специфично формираном просторијом у улици обрађеном као мини трг. На пример, у Народном позоришту улаз је лоциран са бочне стране објекта, наткривен је, садржи мотив који постепено уводи поглед посматрача ка улазу, док зид, постављен под правим углом, завршава визуру. Улаз у Пошту је покривен дубоким улазним тремом, а у визури посматрача истоврмено се комбинују улаз и атријум.

Слика 5. Трг партизана, визура улице у којој се налази Народно позориште (1958) је компонована уз пажљиви баланс између динамичне фасаде позоришта и смирене композиције фасаде стамбеног блока преко пута.

Fig. 5. Partisan's square, the street view of the National Theater (1958), is composed with a careful balance between the dynamic façade of the theater and the tranquil composition of the facade of the residential block across the road

Сл. 6. Трг партизана, плато испред Народног позоришта и Поште. Комбинација камена у неколико начина обраде и зеленила од траве до високог растиња

Fig. 6. Partisan's square, in front of the National Theater and the Post Office: a combination of the stone treated in several ways and greenery

Сл. 7. Трг партизана, улазни мотив у стамбени део блока Запад (1958)

Fig. 7. Partisan's square, the entrance motif in the residential block West (1958)
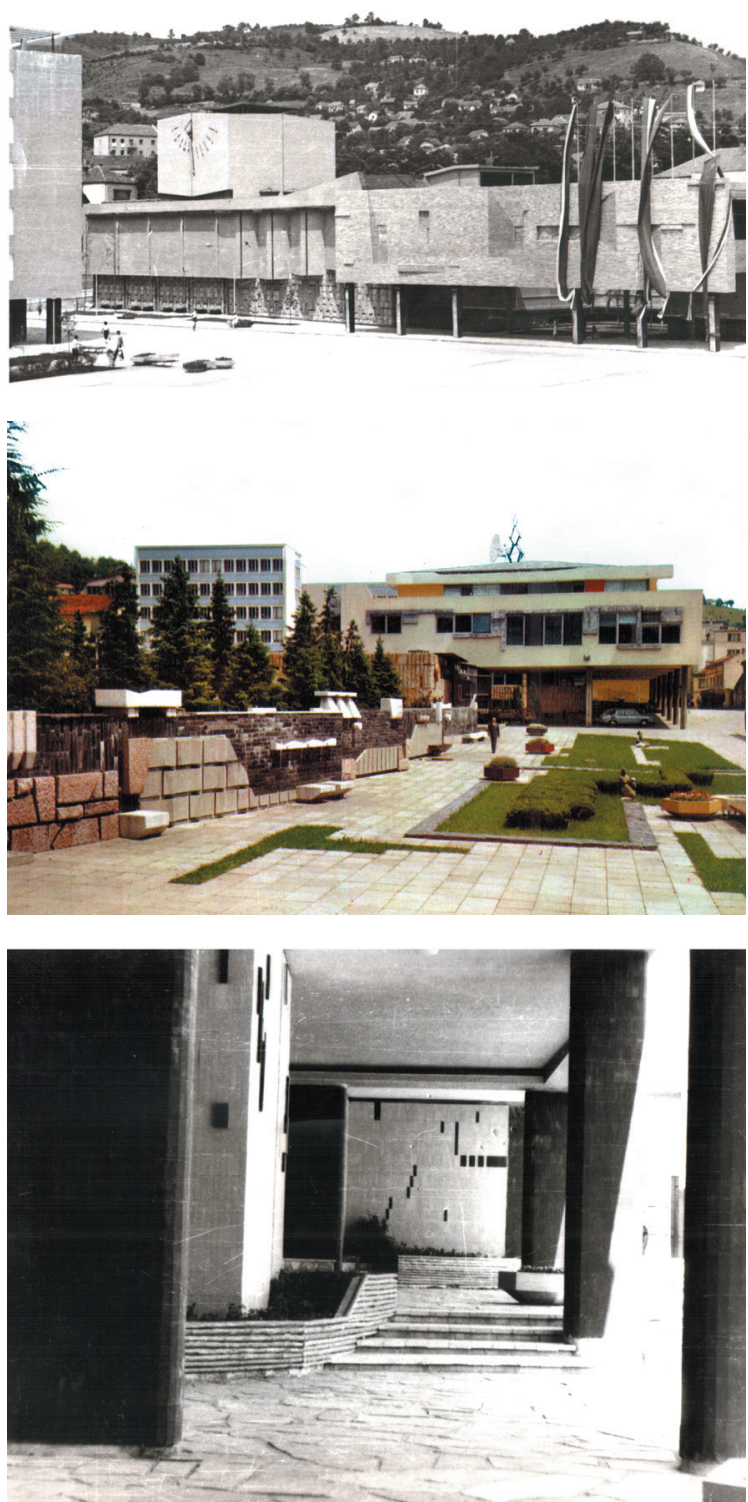

у Робној кући улаз је смештен у средини трема (који покрива пешачку комуникацију), садржи мали претпростор -џеп, а оријентисан је управно на главну фасаду (тако да се сагледава из главног пешачког правца). Улаз у биоскоп је у равни фасаде, налази се у средишту трема који се пружа целом дужином фасаде објекта према Тргу и у могућности је да прихвати скоро све посетиоце, пружајући им могућност да се, када је то потребно, склоне од временских непогода (киша, снег). Улази у пословне локале у приземљу објекта (западни, источни и јужни) су у равни фасаде, а испред њих се налази дубок трем који, такође, штити посетице од временских непогода. (С. 7,8,9)

\section{4. ОБЛИКОВАҢЕ КОНТАКТА ТРГА И УЛИЦЕ}

Нивелете трга су одредиле улице Димитрија Туцовића и Краља Петра (које није било могуће променити пројектом). Околне улице су, уз мале корекције, задржале своје нивелете. Кота Улице Д. Туцовића износи 408,39мнм, најнижи плато има висину од 409,39 на југу и 410,00 на северу, средњи плато има висину од 411,18 на југу и 411,35 на северу, највиши плато има висину од 412,65 на југу и 412,85 на ивици до Улице краља Петра. Плато испред Позоришта има висину од 412,85 на југу и 413,14 на почетку степеништа ка улазу у Народну библиотеку. Плато испред библиотеке има висину од 415,10 метара над морем. Висинска разлика између Улице Димитрија Туцовића и платоа Библиотеке износи 6,71 метар (ИАУ: Пројекат партера). (Слика 8, 9)

Слика 8. Трг партизана, поглед ка југоистоку. Високи објекти и оштар угао којим су уведене улице у простор трга затварају визуру и производе осећај затврености јавног простора

Fig. 8. Partisan's Square, a view towards the southeast. The high buildings and the sharp angle between the streets and the square are closing the sight, creating sense of enclosure of the public space

Слика 9. Трг партизана, поглед ка истоку. Преклапање планова на фасадама објеката и дубоке сенке у приземљима која су колонадом издвојена и истовремено укључена у јавну површину

Fig. 9. Partisan's square, view towards the east: overlapping of plans on the facades of objects, and deep shadows in the ground floor that are separated by the colonnade and simultaneously included in the public space
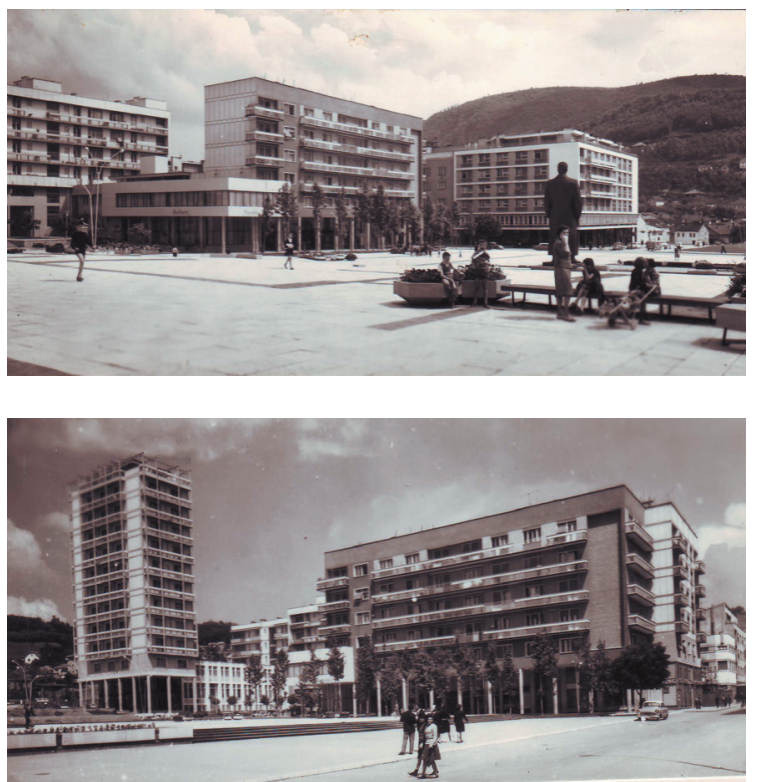
Ширина улица на месту улива у простор трга је од великог значаја за доживљај (Зите, 2011; Арнхајм, 1990) и стварање слике јавног простора (Линч, 1974) -димензије трга износе $84,0 / 120,0$ * 140,00/180,0 метара. Ширина улица (мерено на месту улива у трг) износи: Д. Туцовића 16,5, а Краља Петра 18,0 метара. (Слика 11)

Велики утицај на доживљај трга има начин на који се уводе улице у његов простор, односно угао под којим се улице уливају у трг, висина објеката и ширина улице, обликовање волумена објеката на углу блока итд., као и начин на који се посматрач уводи у простор трга (Зите, 2011). Са запада улаз у трг је наглашен волуменима блока Запад и Народног позоришта -део блока кроз већу спратност формом асоцира на одбрамбену кулу, а са наспрамне стране улице, волумен Позоришта је повучен у односу на грађевинску линију улице. Са истока, мотив који уводи пешака у простор трга формира се објектом Поште и наспрамним блоком Исток. Уколико није било могуће да се мења угао под којим се улица улива у трг, онда је затварана визура из правца трга помоћу обликовања објекта (који се налази на том месту). Кроз визуре које се добијају кроз отворе у објектима, простор трга је повезан са околним улицама. Међутим, отвори у зони партера су постављени под посебним углом у односу на централну површину трга како би се сачувао утисак трга као визуелно затворене целине. Перфорација зидног платна је извршена тако да се сачувају амбијент и

Слика 10. Анализа сагледавања бронзане фигуре из две најважније улице (аутор арх. Станко Мандић)

Fig. 10. Analysis of the visibility of the bronze figure from the two most important streets (author: architect Stanko Mandić)

Слика 11. Трг партизана -високи објекти на угловима

блока уз помоћ веома мале ширине уличног профила затварају визуре са простора трга према граду

Fig. 11. Partisan's square high buildings at the corners of the block with the help of a very small width of the street profile close the vistas from the square to the city затвореност простора трга. Отвори у објектима око трга, у зони приземља, постављени су под правим углом у односу на визуру посматрача и, уместо једног великог, подељени у више мањих отвора, како не би реметили визуелну затвореност трга.

\section{5. КОМПОНОВАҢЕ ВИЗУРА КА ТРГУ И УЛИЦИ}

Компоновање визура из правца трга ка околним улицама доприноси атмосфери интимности трга. Визуре су компоноване тако да су богате у равни, по дубини и карактеру елемената које посматрач сагледава у једном погледу. Визуре су добро планиране у односу на путање којима се усмерава кретање пешака (тротоари, пролази), у односу на планирана места окупљања на површини трга. Такође, визуре су компоноване тако што је узета у обзир висинска разлика између места посматрања и зоне осматрања. Архитекта Мандић је, корак по корак, обликовао и кроз цртеже анализирао, нарочито локацију бронзане фигуре, и то из правца две улице: Д. Туцовића и Краља Петра. Као илустрацију значајно је описати визуру из Улице Д. Туцовића -визура је са јужне стране ограничена високим објекатима (Пр+5), а са северне стране са два волумена (Пр+Ме+5) који се степенасто повлаче и постепено отварају визуру према тргу. На крају визуре се налази фасада објекта Запад. Када сеприступа простору трга отвара се нова визура ка Народном позоришту -са источне стране оквир визуре формирају објекат Куле (Пр+11) и блок Исток, а са западне стране блок Запад и ниско зеленило (осунчање) које отвара поглед ка архитектури блока. У партеру се према бронзаној фигури постепено уздижу три платоа. У средишту композиције се налази бронзана фигура иза које се налази зид-драперија јужне фасаде Народног позоришта. (Слика 1, 5, 10)

\section{6. ЗАКљУЧАК}

Трг партизана је значајно урбанистичко остварење друге Југославије. Многобројне релације између два облика јавног простора (трга и улице) је неопходно анализирати са циљем да се боље разуме и вреднује архитектура периода социјалистичке Југославије и опишу урбанистички алати који су коришћени производећи висок квалитет простора. Трг и улица су пажљиво довођени у међусобне односе при чему се водило рачуна о следећим елементима: ширина улице на месту улива у трг, висина уличног фронта и ширина улице, наглашавање места сустицања улице и трга кроз волумен објеката, угао под којим се улица улива на трг, елементи партера који обликују место сустицања улице и трга, компоновање визура дуж главних пешачких токова, продори у нивоу партера објеката који повезују простор трга са околним улицама, обликовање улаза и улазних мотива у објекте, нивелација партера и улице на месту контакта, начин обликовања фасада према улици и тргу, избор материјала партера на месту додира трга и улице, садржај визуре у оку посматрача, анализа визура из правца главних пешачких токова итд. 

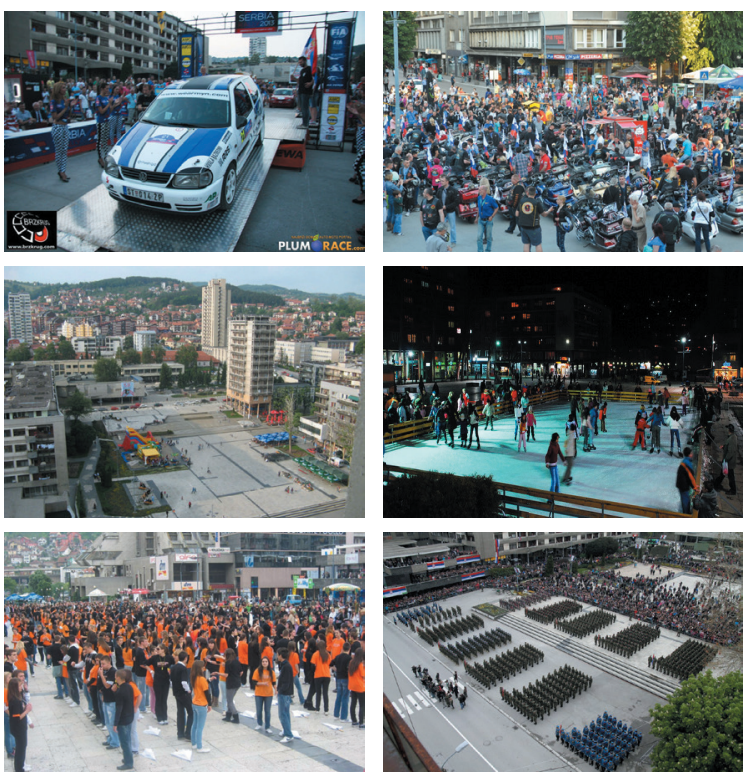

Слика 12. Трг партизана у јавној употреби 1991 - 2015: старт и циљ ауто трке, окупљање мотоциклиста, свакодневна намена током летњих месеци, клизалиште, матурантске свечаности, војна парада

Fig. 12 Partisan's square in the public use 1991 - 2015: start and finish of the car race, motorcyclist gathering, daily use during the summer months, skating rink, graduation ceremony, military parade

Сви наведени елементи су производ искуства које се може наћи у књигама о урбанистичком пројектовању Европе, стећи анализом тргова Балкана, као и производ искуства самог архитекте и његовог талента. Трг партизана је отворен за јавност 1961. год. и од тада је најважнији јавни простор у Ужицу. Мада су се, од отварања трга до данас, неколико пута промениле друштвене вредности и норме, трг и даље успева да на најбољи начин буде оквир јавном животу становника и остане средиште града. Рушењем објекта Поште (1999), неодржавањем партера и објеката доведен је у питање његов опстанак. Јавни конкурси, који су расписани да би поправили стање на тргу, само су потврдили квалитет и вредност решења. Примењени алати у урбанистичком и архитектонском обликовању трга заслужују да буду анализирани. Такође, Трг партизана, квалитетом урбанизма и архитектуре, заслужује да буде проглашен спомеником културне баштине Србије.

\section{ИЗВОРИ}

Историјски архив Ужице

Архив Р. Познановића и М. Искрина из Ужица

Предлог за проглашење Трга партизана спомеником културне баштине, 2015

\section{LITERATURA}

Anonim (1964) Une sympathique tentative d' aménagement de l'espace de la place centrale d'une petite ville de province, L'Architecture d'Aujourd'hui, Février Mars, Paris, p. 112.

Arnhajm, R. (1990) Dinamika arhitektonske forme, Beograd: Univerzitet umetnosti u Beogradu

Brkić, A. (1992) Znakovi u kamenu, srpska moderna arhitektura 1930-1980, Beograd: Savez arhitekata Srbije

Corbusier, L. (1977) Ka pravoj arhitekturi, Beograd: Građevinska knjiga

Corbusier, L., Pierre, F. (1956) Savremena kuća dostojna ljudi, Beograd: Građevinska knjiga Đokić, V. (2004) Urbana morfologija: grad i gradski trg, Beograd: Arhitektonski fakultet Đokić, V. (2009) Urbana tipologija: gradski trg u Srbiji, Beograd: Arhitektonskifakultet
Grupa autora (1992) Istorija Titovog Užica, knjiga 2, Užice

Ilić, Ružica (1953) Titovo Užice, u: Mitrović, M. (ur.), Gradovi i naselja u Srbiji, Beograd: Narodna knjiga, str.120.

Kojić, B. (1970) Varošice u Srbiji XIX veka, Beograd: Građevinska knjiga

Kuzović, D. (2012) Plan Okružnog načelstva i prvostepenog suda u Užicu, Užički zbornik, br. 36, Užice, str.281-303.

Kuzović, D. (2013a) Kuća porodice Stefanović na Trgu Sv. Save u Užicu, Užičcki zbornik, br. 37, Užice

Kuzović, D. (2016b) Arhitektura Narodne biblioteke u Užicu (1961), Zbornik radova Građevinskog fakulteta, Subotica, br. 29, str. 121-131.

Kuzović, D. (2016v) Objekat Kula na Trgu Partizana u Užicu (1961), Zbornik radova Građevinskog fakulteta, Subotica, br. 29, str. 107-120.

Kuzović, D. (2013b) Transformacija urbanog razvoja na primeru prvog urbanističkog plana Užica iz 1863. godine, Arhitektura i urbanizam, br. 36, IAUS, Beograd, str. 68-73.

Kuzović, D. (2013v) Urbanistički plan Užica iz 1891 - ulična mreža i blokovi, Izgradnja, vol. 67, br. 9-10, str. 393-398.

Kuzović, D. (2014a) Generalni plan Užica iz 1891, Glasnik Društva konzervatora Srbije, br. 38, Beograd, str.126-128.

Kuzović, D. (2015a) Urbanistički razvoj Užica u periodu od 1946. do 1956, Izgradnja, vol. 69, br. 3-4, Belgrade, str. 316-324.

Kuzović, D. (2015b) Urbanistički razvoj Užica u 18. i prvoj polovini 19. veka, Zbornik Filozofskog fakulteta u Prištini, br. 4, str. 183-205.

Kuzović, D. (2015g) Generalni plan Užica iz 1971, Izgradnja, Beograd, vol. 69, br. 3-4, str. 141-149.

Kuzović, D. (2015d) Moderna arhitektura u Srbiji - Trg partizana u Užicu, Glasnik Društva konzervatora Srbije, br., 39, Beograd, str.178-183.

Kuzović, D. (2015đ) Bronzana figura na Trgu partizana u Užicu, Glasnik Društva konzervatora Srbije, br. 39, Beograd, str. 43-47.

Kuzović, D. (2015e) Spare the base when you demolish monuments: Interview with prof. dr Mihajlo Mitrović, in: Stiller A., Kovačević, B. (eds.) Serbia - the city as a regional context for architecture, Vienna, pp. 102-118.

Kuzović, D. (2016a) Urbani razvoj civilne varoši Užice od XV do XVII veka, Zbornik Filozofskog fakulteta u Prištini, br. 46-2, str. 391-406.

Kuzović, D. (2017) Kulturne osnove arhitekture Moderne u Jugoslaviji (1945-1990), primer Trga partizana u Užicu (1961). Kultura, br. 154/2017, Beograd: Zavod za proučavanje kulturnog razvitka, str. 300-314.

Linč, K. (1974) Slika jednog grada, Beograd, Građevinska knjiga

Maksimović, M. (1965) Arh. Stanko Mandić: Stvarati arhitekturu - znači li rizikovati?, Politika, 16.08.1965, str. 20

Mandić, S. (1959) Gradski trg u Titovom Užicu, Funkcija i kompozicija arhitekture prostora - razmatranja, paralele, ogledi, Beograd, Arhitektonski fakultet Univerziteta u Beogradu

Marković, Ž. (2008) Carigradski Memento, Užice, Istorijski arhiv

Marković, Ž., Stanimirović, A. (1990) Kulturno-istorijsko spomeničko nasleđe Titovog Užica, Užički zbornik, br. 19, Titovo Užice, Narodni muzej Užice, str. 67.

Milenković, B. (1962) Trg Partizana u Titovom Užicu, Arhitektura i Urbanizam, br. 13, Beograd, str. 1-3.

Milivojević, D. (2013) Iz istorije nastanka Trga partizana u Užicu, Izgradnja, br. 67, Beograd, str. 314-328.

Milivojević, D. (ur.) (2014) Između iskoraka i pomirenja, arhitektura Stanka Mandića Užice, izdanje urednika

Mitrović, M. (1965) Primer koji otvara oči (Rezultati postignuti u izgradnji Titovog Užice ostali su usamljeni), Politika, 21.03.1965, str. 17.

Ciganović, A. (2013) Izgradnja Trga partizana u Užicu: između ideje savremenosti i nesavremenosti, Izgradnja, vol. 67, br. 11-12, Beograd, Udruženje, str. 486-497.

Zite, K. (2011) Umetničko oblikovanje gradova, Beograd, Građevinska knjiga

\section{POREKLO ILUSTRACIJA}

Slika 1,3,10, Mandić, S. (1959) Gradski trg u Titovom Užicu, Funkcija i kompozicija arhitekture prostora - razmatranja, paralele, ogledi, Beograd, Arhitektonski fakultet

Slika 4,12, Internet sources (Oreska.net, Užice.net, vesti.rs)

Slika 2, Autor

Slika 3, Arhiv Užice

Slika 5,6,7,08,11, Arhiva R. Poznanovića/M. Iskrina iz Užica 